Limnol. Rev. (2016) 16, 1: 33-39

\title{
A proposal of protection techniques in the catchment of a lake in the context of improving its recreational value
}

\author{
Jolanta Grochowska, Renata Tandyrak, Katarzyna Parszuto, Renata Brzozowska \\ Department of Water Protection Engineering, Faculty of Environmental Sciences, University of Warmia and Mazury in Olsztyn, \\ Prawocheńskiego 1, 10-720 Olsztyn, Poland, e-mail: jgroch@uwm.edu.pl (corresponding author)
}

\begin{abstract}
The study was carried out on Lake Rentyńskie (100.8 ha; $9.4 \mathrm{~m}$ ) situated approximately $20 \mathrm{~km}$ to the west of Olsztyn, in the drainage basin of the rivers Giłwa and Pasłęka. The direct catchment area of the lake is 166.2 ha. Forests cover most of the drainage basin area $(74 \%)$. As revealed in the study, Rentyńskie is a highly eutrophic reservoir. The lake waters were characterized by a high content of nutrients, up to $1.508 \mathrm{mg} \mathrm{P} \mathrm{dm}^{-3}$ and $11.7 \mathrm{mg} \mathrm{N} \mathrm{dm}^{-3}$. The high fertility of the lake was also evident in the values of chlorophyll $a-$ $75.4 \mu \mathrm{g} \mathrm{dm}^{-3}$, and low water transparency - average $1 \mathrm{~m}$. The total annual phosphorus and nitrogen load to Lake Rentyńskie, calculated according to Giercuszkiewicz-Bajtlik (1990) equals $759.0 \mathrm{~kg}$ of phosphorus and $31869.7 \mathrm{~kg}$ of nitrogen, or per unit surface $0.753 \mathrm{~g} P$ $\mathrm{m}^{-2} \mathrm{yr}^{-1}$ and $31.611 \mathrm{~N} \mathrm{~m}^{-2} \mathrm{yr}^{-1}$. Allowable and critical load levels to Lake Rentyńskie calculated according to the hydrological model of Vollenweider (1976) equal (respectively) $0.090 \mathrm{~g} \mathrm{P} \mathrm{m}^{-2} \mathrm{yr}^{-1}$ and $0.189 \mathrm{~g} \mathrm{P} \mathrm{m}^{-2} \mathrm{yr}^{-1}$. From a comparison between the actual phosphorus load and the values calculated according to Vollenweider it can be concluded that the loads not only exceed the allowable values by several times but also the critical values responsible for advanced eutrophication. The study showed that the River Giłwa, which flows through the reservoir, posed a major threat to the analysed lake. In order to improve the water quality in Lake Rentyńskie drastic protective measures should be taken in the basin of the River Giłwa, which is intensively used for agriculture, and also, at the point where the river enters the lake a special system to reduce the level of phosphorus compound concentrations should be set up.
\end{abstract}

Key words: trophic state, catchment, nutrients, recreational value

\section{Introduction}

Recreational potential forms part of the total potential of the natural environment (Kistowski 1996) and has been defined by Haase (1978) as the ability of nature to satisfy human needs related to leisure activities, renovation of biopsychophyscial forces and aesthetic sensations. The size of the recreational potential for the concerned area is specified in terms of its surface features, forest cover, land mosaic, lake density, quality of atmosphere, and especially the purity of lakes. Recreational potential rises with a higher quality of lake water.

Lakes have better water quality when they are loaded to a small degree by mineral and organic matter from the catchment area, which stimulates the eutrophication process (Jorgensen 2001; Carpenter 2008; Fraterrigo and Downing 2008; Istvánovics 2009; Grochowska et al. 2011). Water reservoirs which are surrounded by areas with a clear influence of anthropogenic pressure (urbanization, agriculture, supply of rainwater and domestic sewage) are generally characterized by low water quality and high trophic status (Bennet et al. 2001; Malmaeus and Håkanson 2004; Wang et al. 2012; Grochowska et al. 2015). The consequences of reservoir overloading by mineral and organic matter are phytoplankton blooms and low water transparency, high concentration of nutrients and disturbances in the oxygen systems. Protective actions in the catchment area are undertaken in order to minimize the external loading of a lake and thus slow down the eutrophication process and also improve the recreational value of the reservoir (Jeppesen et al. 2007). Gawrońska and Lossow (2003) and Reynolds (2003) point out that the measures in the catchment area are arduous, lengthy and not very spectacular, but they are necessary and in some cases may lead to selfreaction of reservoir and a return to its original state. 
Cooke et al. (2005) have provided many solutions for eliminating or reducing external sources of nutrients (protection of lakes). The first and most important protective method is to cut off the flow of sewage into the lake and redirect this flow beyond the catchment area. In addition, leaky septic tanks and other uncontrolled discharges of pollutants should be identified and eliminated. If lakes are surrounded by agricultural areas, it may be necessary to change the land use practices in the catchment and reduce the amount of arable land in favor of grassland.

Lake Rentyńskie is located in an area which is attractive for tourism and recreation. The direct neighborhood of the reservoir is covered by fresh coniferous forests, mixed coniferous forests and dry ground forests. Gietrzwałd town with its famous Marian Sanctuary lies at a distance of approximately 1.5 $\mathrm{km}$ southwest of the lake. Unfortunately, the lake is a highly eutrophic reservoir which very much limits its economic usefulness.

The objective of paper is to describe the loading of Lake Rentyńskie by nutrients from the direct catchment and the inflow of surface water, in comparison with the acceptable and critical load calculated according to the hydrological model of Vollenweider (1976) and also to offer a practical proposal for the catchment area, which can improve the trophic status of the lake and its recreational value.

\section{Material and methods}

Lake Rentyńskie is located approximately 20 $\mathrm{km}$ west of Olsztyn, in the Giłwa-Pasłęka drainage basin. The geographic coordinates are $53^{\circ} 46^{\prime} 2^{\prime \prime} \mathrm{N}$ and $20^{\circ} 14^{\prime} 2^{\prime \prime} \mathrm{E}$. To the north the lake is adjacent to Rentyny village. The lake axis runs from north-west to south-east. The surface area is 100.8 ha and the maximum depth is $9.4 \mathrm{~m}$ (Table 1). Detailed morphometric parameters are given in Table 1.

Lake Rentyńskie is a flow-through reservoir. The River Giłwa enters the lake from the south and flows out from the north-western side (Fig. 1).

Table 1. Detailed morphometrical data of Lake Rentyńskie according to Institute of Inland Fisheries in Olsztyn (IRŚ 1964)

\begin{tabular}{lcc}
\hline \multicolumn{1}{c}{ Parameter } & Unit & Values \\
\hline Water surface area & {$[\mathrm{ha}]$} & 100.8 \\
\hline Maximum depth & {$[\mathrm{m}]$} & 9.4 \\
\hline Mean depth & {$[\mathrm{m}]$} & 3.7 \\
\hline Relative depth & - & 0.0094 \\
\hline Depth index & - & 0.39 \\
\hline Volume & {$\left[\mathrm{dam}^{-3}\right]$} & 3722.2 \\
\hline Maximum length & {$\left[\mathrm{m}^{-}\right.$} & 2.2 \\
\hline Maximum width & {$[\mathrm{m}]$} & 0.6 \\
\hline Elongation & - & 3.7 \\
\hline Shoreline length & {$[\mathrm{km}]$} & 6.8 \\
\hline Shoreline development & - & 1.95
\end{tabular}

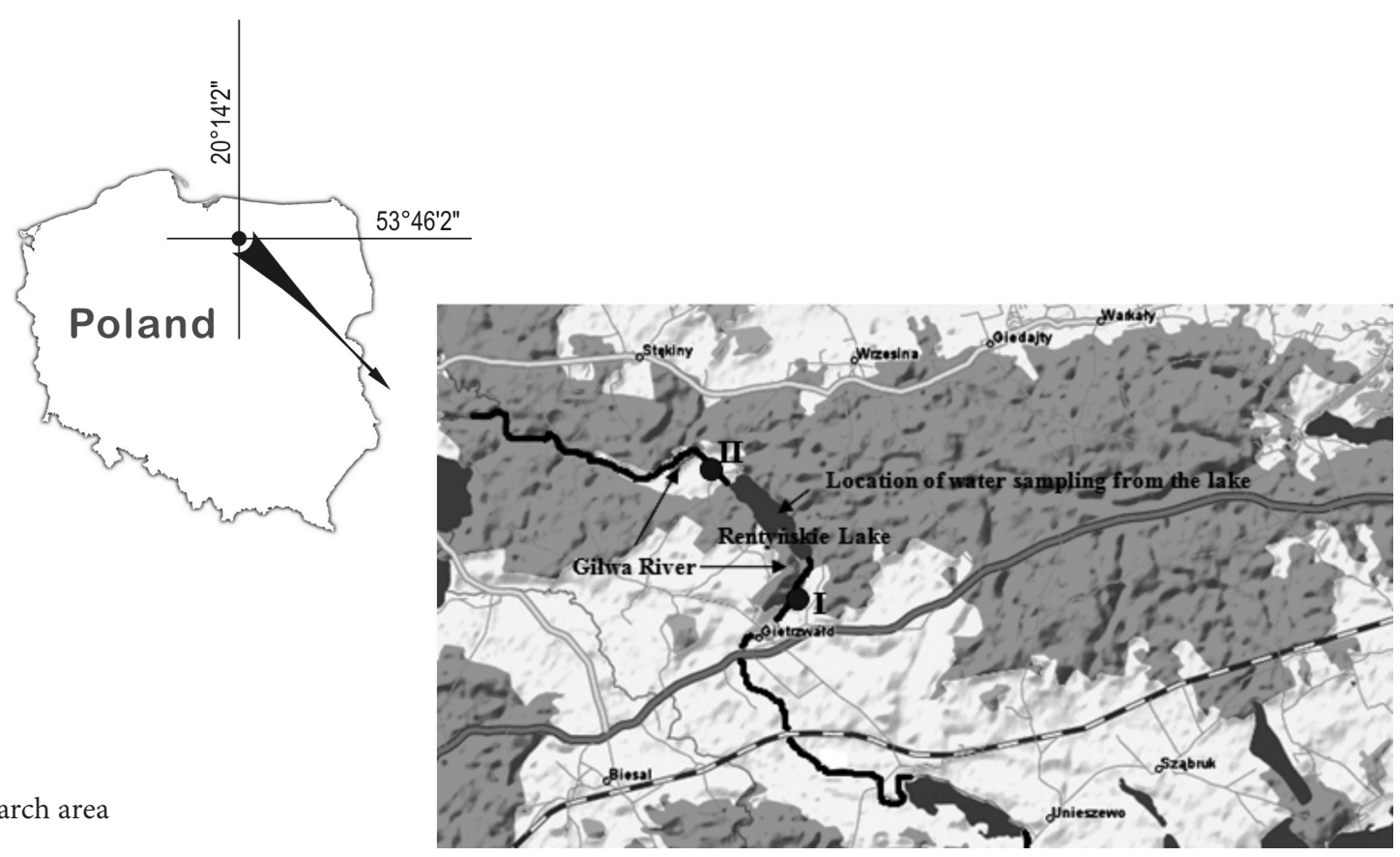

Fig. 1. Research area 
The analyses of the physico-chemical properties of Lake Rentyńskie water were made in the spring (April), summer (August) and autumn (November) of 2014. Water for analyses was taken from the deepest site in the lake, localized by using a bathymetric chart, GPS and sonar (Fig. 1). Water samples were taken from $1 \mathrm{~m}$ depth under the water surface and 1 $\mathrm{m}$ above the bottom. Simultaneously, temperature and DO were measured at every meter of the water column depth with an optical type proODO oxygen sensor (YSI company). Water transparency was measured with a Secchi disc. Water reaction $(\mathrm{pH})$ and electrolytic conductivity were measured using a MultiLine F/ SET-3 WTW probe.

Hydrochemical measurements of the River Giłwa inflow (I) and outflow (II) (Fig. 1) were made from November 2013 to October 2014 in order to determine the external nutrient load to Lake Rentyńskie. Morphometric measurements of the watercourse (depth, width) were taken and water velocity was measured with a VALEPORT (model 801) electromagnetic flowmeter. Momentary flow was calculated using the method by Harlacher (Bajkiewicz- Grabowska and Magnuszewski 2009). Chemical analyses were carried out in accordance with Hermanowicz et al. (1999).

The surface of Lake Rentyńskie catchment was determined on the basis of a topographic map at a scale of 1:10,000 and field observations in the case of a dubious course of a given water divide. Measurements of the catchment surface were taken with polar (PL-1) and cylinder (KP90N) planimeters (SOKKIA, Japan). Methods and recommendations described by Bajkiewicz-Grabowska and Magnuszewski (2009) were followed when topographic water divides were applied. The calculations of the amount of biogenic substances that are annually brought to the lakes with watercourses or from bank outlets were performed based on their actual concentration in water flows measured on the individual stations during yearly field studies. The partial load for a given day was the product of the volume of water (momentary flow) and the concentration of a given nutrient in water. Biogene loads were calculated with a generally accepted method of time periods. The magnitude of a lake load with nutrients originating from surface flows from the direct catchment was calculated with a method that is recommended and applied by OECD (Vollenweider and Kerekes 1982); this method consists of calculating the loads with flow coefficients (Giercuszkiewicz-Bajtlik 1990) which depend on the method of land manage- ment, use and the denivelation surface of a given area. The load of biogenes introduced to a given lake with precipitation was determined based on the coefficients of pollution deposition per surface unit (a lake in this case) that is annually published by the Voivodship Inspectorate of Environmental Protection in Olsztyn. In 2014 in the Warmian-Masurian Voivodeship, these values were $0.349 \mathrm{~kg} \mathrm{P} \mathrm{ha} \mathrm{yr}^{-1}$ and $7.080 \mathrm{~kg} \mathrm{~N} \mathrm{ha}^{-1}$ $\mathrm{yr}^{-1}$. In order to calculate the allowable and dangerous (critical) loadings of phosphorus the hydrological model of Vollenweider (1976) was applied.

The assessment of the lake's trophic status was based on trophic indicators as proposed by Carlson (1977), and Kratzer and Brezonik (1981).

\section{Results and discussion}

Lakes are dynamic ecosystems that change over time and contribute to the enrichment and intensification of biological productivity. It is a well-known fact (Grochowska et al 2011) that eutrophication runs slower in lakes with lower water dynamics and that they are less vulnerable to human pressure. Lake Rentyńskie is not very deep $(9.4 \mathrm{~m})$ but relatively large (100.8 ha). However, to the west, south and partly to the east it is surrounded by a forest that considerably limits access to the water table. Moreover, it is a flowthrough reservoir, although this aspect is less evident. Taking into account the criteria given by Patalas (1960) the lake can be classified as belonging to the 3rd static degree.

Eutrophication of a lake is demonstrated by the concentrations of nutrients, particularly $\mathrm{N}$ and $\mathrm{P}$ (Conley et al 2009). Quantities of both elements in the water of Lake Rentyńskie were high, up to $1.51 \mathrm{mg} P$ $\mathrm{dm}^{-3}$ and $11.7 \mathrm{~N} \mathrm{mg} \mathrm{dm}^{-3}$ (Fig. 2). Total $\mathrm{P}$ was dominated by the organic form with the exception of the peak of the summer stagnation when the dominant $\mathrm{P}$ form in the near-bottom water was phosphate (1.12 $\mathrm{mg} \mathrm{P} \mathrm{dm}^{-3}$ ) (Fig. 2), the reason being the release of mineral $\mathrm{P}$ from the bottom sediments during a heavy oxygen deficit. The overall amount of nitrogen compounds in the lake was dominated by the organic form. Mineral N occurred in the lake waters constantly and in high concentrations (Fig. 2). Mineral forms of $\mathrm{N}$ were dominated by ammonium and nitrate. On one hand, the mineral forms of $\mathrm{N}$ present in the water throughout the whole vegetative period indicate the abundance of $\mathrm{N}$ but on the other hand - the intensive mineralization and nitrification of the water. 

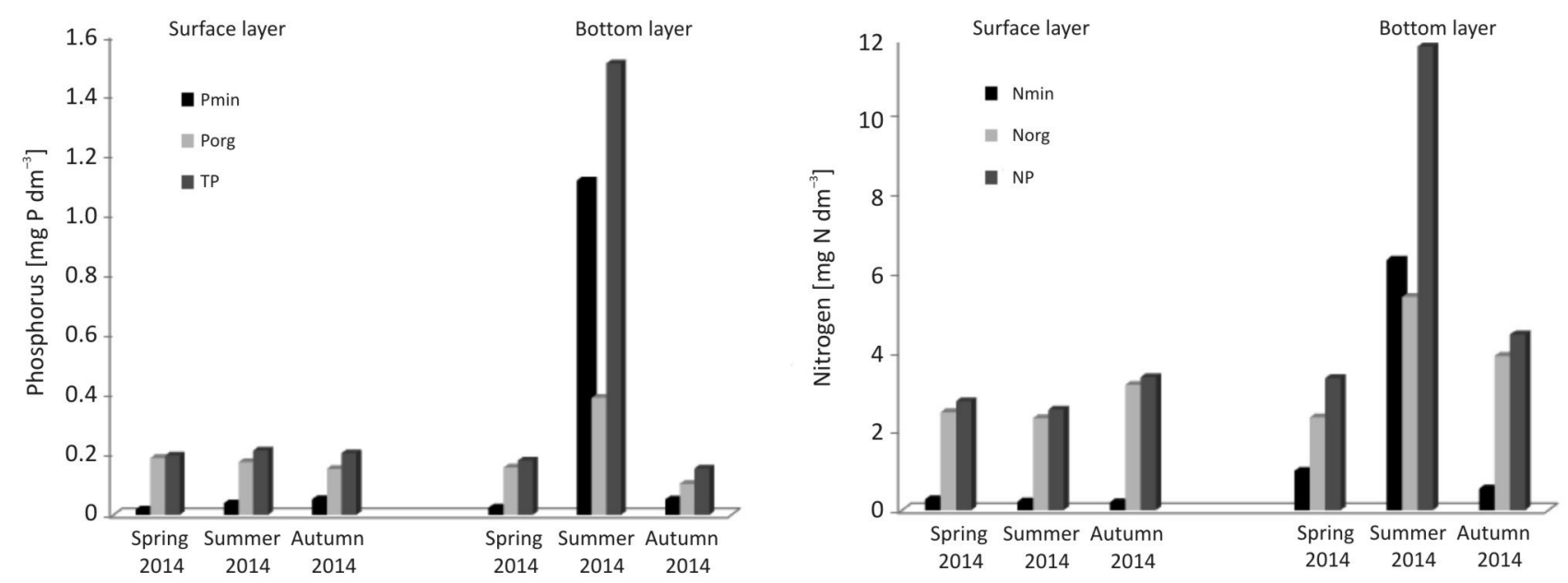

Fig. 2. Seasonal changes of nutrient concentrations in Lake Rentyńskie waters

One of the indicators of excessive water fertility is low water transparency. Water transparency in Lake Rentyńskie ranged from 0.50 to 1.50 m (Fig. 3) and oscillated during the vegetation period around the value of $0.75 \mathrm{~m}$. An excessive biomass of algae is the limiting factor for sunlight penetration in the lake, as shown by the highest amount of chlorophyll $a$ (indicator of primary production, equal to $75.40 \mu \mathrm{g} \mathrm{dm}^{-3}$ ) that occurred simultaneously with the lowest water transparency $(0.50 \mathrm{~m})$ (Fig. 3).

Taking into account the trophy indicators such as the summer measurements of nutrients concentrations (total nitrogen and phosphorus), chlorophyll $a$ concentration, and Secchi disc visibility (Carpenter et al. 1998; Håkanson and Boulion 2001) a Carlson-type trophic state indices were calculated - TSI (Trophic State Index) (Carlson 1977; Kratzer and Brezonik 1981).

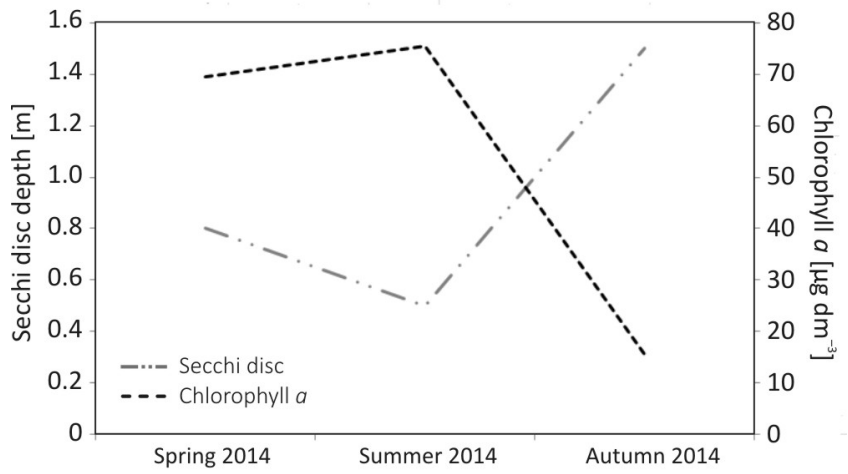

Fig. 3. Seasonal changes in water transparency (Secchi disc depth) and chlorophyll a concentration in Lake Rentyńskie
Analysis of the point scale of TSI showed that Lake Rentyńskie is a hypertrophic reservoir or heavily degraded. Indexes calculated on basis of phosphorus concentrations and visibility exceeded the value of TSI 70. In the case of TSI(TN) and TSI(Chl) they were similar to 70 (Fig. 4). With such high concentrations of phosphorus and organic matter there is no chance of any natural inhibition from such strong degradation of the reservoir, hence there exists a necessity for the application of protective measures and even recultivation for reducing the amount of phosphorus, and consequently lowering the size of primary production.

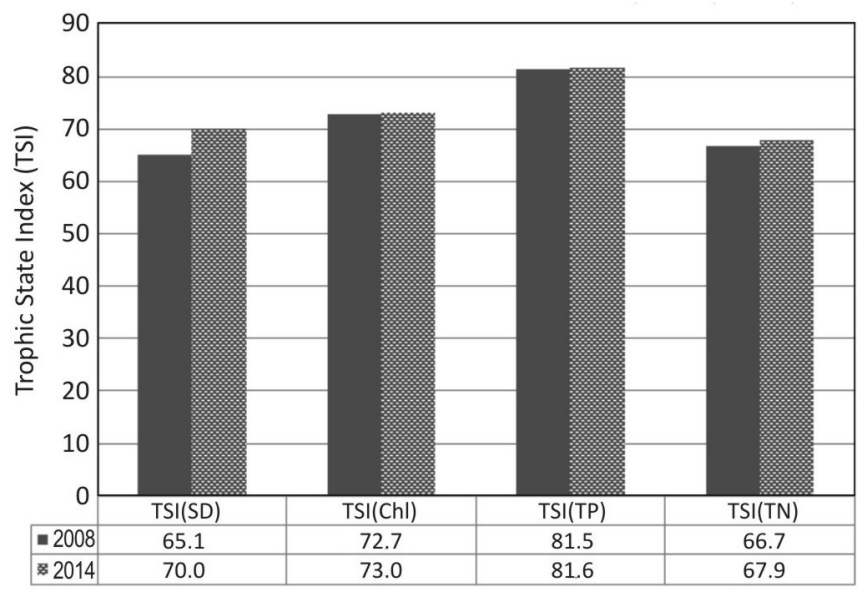

Fig. 4. Trophic State Index (TSI) calculated for Secchi disc transparency (SD), and chlorophyll a (Chl), total phosphorus (TP) and total nitrogen (TN) concentrations 
The hypertrophic state of Lake Rentyńskie is also confirmed by the international classification of OECD (1982) (Table 2). Repeatedly exceeded values for hypertrophy indicate that the reservoir is not able to "defend itself" against the products of their metabolic processes.

Table 2. Value ranges of main parameters of trophic level for lakes according to OECD classification (Vollenweider and Kerekes 1982) and measured values for Lake Rentyńskie (average of two measurements - early and late summer) in the years 2008 and 2014

\begin{tabular}{|c|c|c|c|c|c|c|c|}
\hline \multirow{2}{*}{ Parameter } & \multirow{2}{*}{$\mathrm{O}$} & \multirow{2}{*}{ M } & \multirow{2}{*}{$E$} & \multirow{2}{*}{$\mathrm{H}$} & \multicolumn{2}{|c|}{ Lake Rentyńskie } & \multirow{2}{*}{ Trophic state } \\
\hline & & & & & 2008 & 2014 & \\
\hline Total Phosphorus [ $\left.\mu \mathrm{g} \mathrm{P} / \mathrm{dm}^{3}\right]$ & $<10$ & $10-35$ & $35-100$ & $>100$ & 300 & 300 & Hypertrophy \\
\hline Chlorophyll a $\left[\mathrm{gg} \mathrm{dm}^{-3}\right]$ & $<2.5$ & $2.5-8.0$ & $8-25$ & $>25$ & 115 & 55 & Hypertrophy \\
\hline Secchi disc depth [m] & $>6$ & $6-3$ & $3-1.5$ & $<1.5$ & 0.3 & 0.4 & Hypertrophy \\
\hline
\end{tabular}

O - oligotrophy, M - mesotrophy, E - eutrophy, H - hypertrophy

It is certain that the highly advanced eutrophication processes in Lake Rentyńskie are stimulated by the excessive input of nutrients from the drainage basin, especially through the River Giłwa. The total catchment area of Lake Rentyńskie is 11820 ha, and the direct catchment area $166.2 \mathrm{ha}$. The largest part of the direct catchment area is covered by forests, which constitute up 74\% (Fig. 5). Other forms of land use in the immediate vicinity of the reservoir are: built-up areas (6\%) and arable land (4\%). The watershed draining indirectly to the lake is dominated by agricultural lands.

The average flow rate at the mouth of the River Giłwa to the analysed lake was $0.173 \mathrm{~m} \mathrm{~s}^{-1}$, and the mean nutrient concentrations: $0.127 \mathrm{mg} \mathrm{P} \mathrm{dm}^{-3}$ and $5.504 \mathrm{mg} \mathrm{N} \mathrm{dm}^{-3}$.

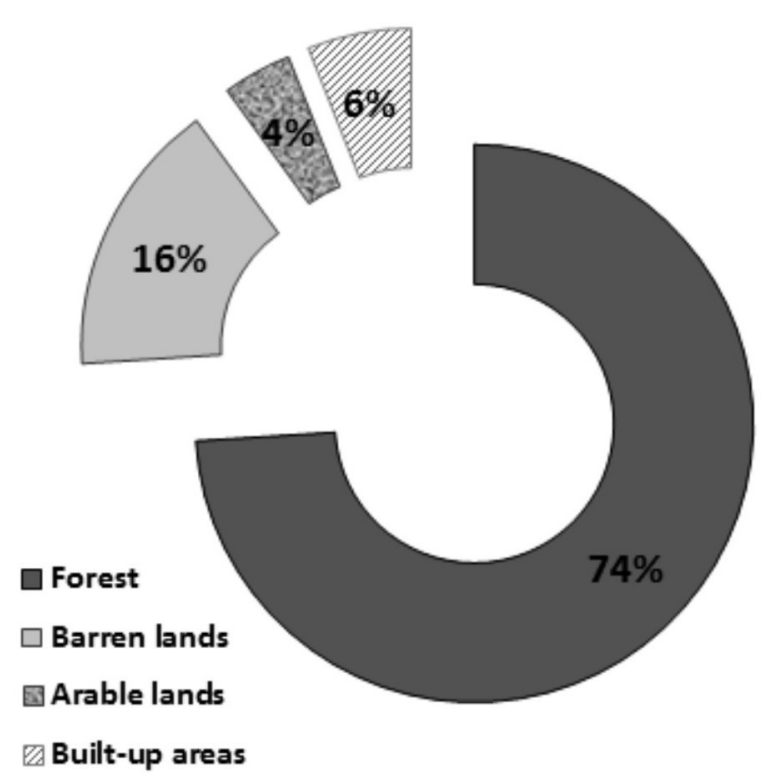

Fig. 5. Land use in the direct watershed of Lake Rentyńskie
The data presented in Table 3 show that the total annual phosphorus and nitrogen load to Lake Rentyńskie, calculated according to GiercuszkiewiczBajtlik (1990) equals $759.0 \mathrm{~kg}$ of phosphorus and $31869.7 \mathrm{~kg}$ of nitrogen, or per unit surface $0.753 \mathrm{~g} \mathrm{P}$ $\mathrm{m}^{-2} \mathrm{yr}^{-1}$ and $31.611 \mathrm{~g} \mathrm{~N} \mathrm{~m}^{-2} \mathrm{yr}^{-1}$.

Table 3. Annual loading of nitrogen and phosphorus to Lake Rentyńskie

\begin{tabular}{lcc}
\hline \multirow{2}{*}{ Sources } & \multicolumn{2}{c}{ Loading } \\
\cline { 2 - 3 } & Phosphorus & Nitrogen \\
\cline { 2 - 3 } & {$\left[\mathrm{kg} \mathrm{yr}^{-1}\right]$} & {$\left[\mathrm{kg} \mathrm{yr}^{-1}\right]$} \\
\hline Surface supply & 44.9 & 1030.5 \\
\hline Recreation & 0.2 & 4.5 \\
\hline Atmospheric deposition & 20.2 & 806.4 \\
\hline River Giłwa & 693.8 & 30028.3 \\
\hline Total & 759.0 & 31869.7 \\
\hline
\end{tabular}

Allowable and critical load levels to Lake Rentyńskie calculated according to the hydrological model of Vollenweider (1976) equal (respectively) $0.090 \mathrm{~g} \mathrm{P} \mathrm{m}^{-2} \mathrm{yr}^{-1}$ and $0.189 \mathrm{~g} \mathrm{P} \mathrm{m}^{-2} \mathrm{yr}^{-1}$. From a comparison between the actual phosphorus load and the values calculated according to Vollenweider (1976) it can be concluded that the loads not only exceed the allowable values by several times not only but also the critical values responsible for advanced eutrophication (Fig. 6).

Grochowska and Tandyrak (2010) who examined Lake Rentyńskie earlier (2008) described the reservoir as highly eutrophic. The present study of the lake confirmed the deterioration in the water quality. High nutrient loads from the drainage basin clearly illustrate the great need to apply protective actions 


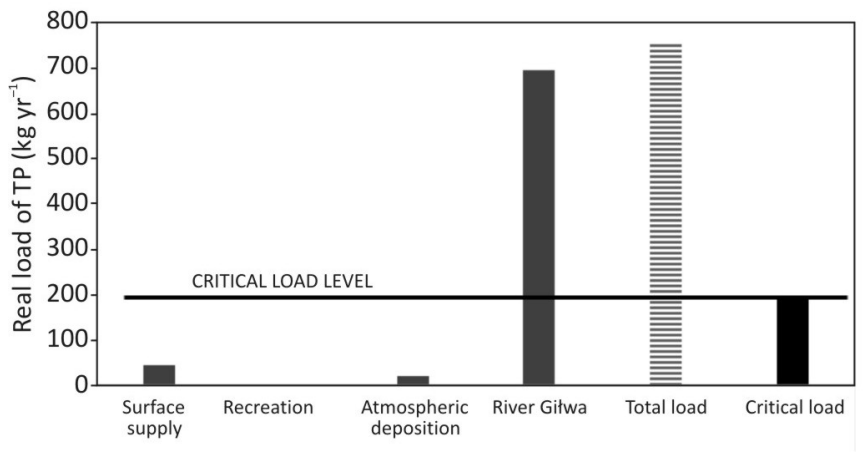

Fig. 6. Mean annual external total phosphorus load to Lake Rentyńskie versus critical load calculated according to hydrological model of Vollenweider (1976)

that would diminish the external loading and improve recreational values. The study revealed that the major threat to the analysed lake is the River Giłwa which flows through the reservoir. The catchment of the River Giłwa (the section from the Unieszewo fishponds to Gietrzwałd) undergoes intensive agriculture usage. In order to reduce the nitrogen compound load introduced with the River Gilwa the following consecutive measures should be undertaken: elimination of root crops (such as potatoes, carrots, beets) that require multiple hoeing during the growing season and plants that require large amounts of fertilizers and plant protection (the type of cultivation was noted during the field study) for papilionaceous plants, avoidance of monocultures and arable land on slopes with a drop of more than $10 \%$, and plowing across the slope, which slows down runoff water and nutrients by up to 40 to $60 \%$. The rational management of fertilizers can be practised by adjusting the doses of fertilizer to the nutritional needs of plants and adherence to the appropriate ratio of N:P:Kso as to achieve the most effective absorption of fertilizer, and the use of fertilizers on snow and frozen soil should be prohibited. Using manure is preferred, instead of mineral fertilizers. A technical solution is to set up a sediment-filter system in the riverbed in the form of filling sections. These devices, in the form of polypropylene and PCV moulders with a cross-current flow are characterized by the high activity with which growing micro-organisms on the biofilm can purify water on the basis of biological deposits. In addition, a sand-gravel filter with an activated chemistry sorbent should be built at a point before the river enters the lake. This could reduce the phosphorus load imported with water from the River Giłwa.
The proposed treatments would effectively eliminate the loads of pollutants that flow into the lake and would certainly bring about a highly positive outcome for the environment.

\section{References}

Bajkiewicz-Grabowska E., Magnuszewski A., 2009, Przewodnik do ćwiczeń z hydrologii ogólnej (Exercise guide to general hydrology), Wydaw. Nauk. PWN Warszawa, 195 pp. (in Polish).

Bennet E.M., Carpenter S.R., Caraco N.F., 2001, Human impact on erodable phosphorus and eutrophication: A global perspective, Bioscience 51: 227-232.

Carlson R.E., 1977, A trophic state index for lakes, Limnol. Oceanogr. 22(2): 361-369.

Carpenter S.R., 2008, Phosphorus control is critical to mitigating eutrophication, Proc. Nat. Acad. Sci. USA 105: 11039-11040.

Carpenter S.R., Cole J.J., Kitchell J.F., Pace M.L., 1998, Impact of dissolved organic carbon, phosphorus, and grazing on phytoplankton biomass and production in experimental lakes, Limnol. Oceanogr. 43(1): 73-80.

Conley D.J., Paerl H.W., Howarth R.W., Boesch D.F., Seitzinger S.P., Havens K.E., Lancelot Ch., Likens G.E., 2009, Controlling Eutrophication: nitrogen and phosphorus, Science 323: 1014-1015.

Cooke G.D., Welch E.B., Peterson S.A., Newroth P.R., 2005, Restoration and management of lakes and reservoirs, CRC Press, Boca Raton, 591 pp.

Fraterrigo J.M., Downing J.A., 2008, The influence of land use on lake nutrients varies with watershed transport capacity, Ecosystems 11(7): 1021-1034.

Gawrońska H., Lossow K., 2003, Possibilities of a saprotrophic lake recultivation exemplified by Lake Długie in Olsztyn, Pol. J. Environ. Stud. 12(3): 301-307.

Giercuszkiewicz-Bajtlik M., 1990, Prognozowanie zmian jakości wód stojących (Forecasting of the changes of stending waters quality), IOŚ, Warszawa, 69 pp. (in Polish).

Grochowska J., Brzozowska R., 2015, Influence of different recultivation methods on durability of nitrogen compounds changes in the waters of an urban lake, Water Environ. J. 29(2): 228-235

Grochowska J., Tandyrak R., 2010, Water chemistry of Lake Giłwa, J. Elementol. 15(1): 19-29.

Grochowska J., Wiśniewski G., Tandyrak R., 2011, Productivity of lakes varying in water mass dynamics, Limnol. Rev. 11(1): 7-13.

Haase G., 1978, Zur Ableitang und Kennzeichnung von Naturpotentialen, Pettermanns Geogr. Mitt. 122(2): 113125 (in German).

Håkanson L., Boulion V.V., 2001, Regularities in primary production, Secchi depth and fish yield and a new system to define trophic and humic state indices for lake ecosystems, Int. Rev. Hydrobiol. 86(1): 23-62. 
Hermanowicz W., Dojlido J., Dożańska W., Koziorowski B., Zerbe J., 1999, Fizyczno-chemiczne badanie wody i ścieków (Physical-chemical examination of water and wastewater), Wydaw. Arkady, Warszawa, 556 pp. (in Polish).

[IRŚ] Instytut Rybactwa Śródlądowego (Inland Fisheries Institute), 1964, Mapa batymetryczna i karta morfometryczna jeziora Giłwa (Bathymetric map and morphometric card of Lake Giłwa), IRS, Olsztyn, 2 pp.

Istvánovics V., 2009, Eutrophication of lakes and reservoirs, [in:] Likens G.E. (ed.), Encyclopedia of Inland Waters. Vol. 1, Elsevier, Oxford: 157-165.

Jeppesen E., Søndergaard M., Meerhoff M., Lauridsen T.L., Jensen J.P., 2007, Shallow lake restoration by nutrient loading reduction - some recent findings and challenges ahead, Hydrobiologia 584: 239-252.

Jorgensen S.E., 2001, Water quality, The impact of eutrophication, Lake Reserv. Manage. 3: 15-18.

Kistowski M., 1996, Metody oceny potencjału krajobrazu obszarów młodoglacjalnych (The method of estimation of the young-glacial areas landscape potential), Prz. Geogr. 63(3-4): 367-386 (in Polish, English summary). Kratzer C.R., Brezonik P.L., 1981, A Carlson - type trophic state index for nitrogen in Florida lakes, Water Res. Bull. 17(4): 713-715.
Malmaeus J.M., Håkanson L., 2004, Development of a lake eutrophication model, Ecol. Model. 171: 35-63.

Patalas K., 1960, Mieszanie wody jako czynnik określający intensywność krążenia materii w różnych morfologicznie jeziorach okolic Węgorzewa (The mixing of the water as a factor determine intensity of the matter turnover in different morphological lakes near Węgorzewo), Rocz. Nauk Rol. 77B(1): 223-242 (in Polish, English summary).

Reynolds C.S., 2003, The development of perceptions of aquatic eutrophication and its control, Ecohydrol. Hydrobiol. 3: 149-163.

Vollenweider R.A., 1976, Advances in defining critical loading level for phosphorus in lake eutrophication, Mem. Inst. Ital. Idrobiol. 33: 53-83.

Vollenweider R.A., Kerekes J., 1982, Eutrophication of waters. Monitoring, assessment and control. OECD Cooperative programme on monitoring of inland waters (Eutrophication control), Environment Directorate, OECD, Paris. 154 pp.

Wang J., Zhang K., Liang B., 2012, Tracing urban sewage pollution in Chaohu lake (China) using linear alkyl benzenes (LABs) as molecular marker, Sci. Total Environ. 414: 356-363. 
